\title{
Students' Opinions, Views, and Perceptions of Science Laboratory Learning: A Systematic Review of the Literature
}

\author{
Christian Bob Nicol $^{1 *}$ (D), Emmanuel Gakuba ${ }^{2}$ (D), Gonzague Habinshuti ${ }^{3}$ \\ ${ }^{1}$ African Centre of Excellence for Innovative Teaching and Learning Mathematics and Science, College of Education, University of \\ Rwanda, RWANDA \\ 2 Department of Mathematics, Science and Physical Education, College of Education, University of Rwanda, RWANDA \\ ${ }^{3}$ School of Inclusive and Special Needs Education, College of Education, University of Rwanda, RWANDA
}

Received 8 October 2021 - Accepted 27 January 2022

\begin{abstract}
The scientific community continues to give conflicting impressions about the contribution of laboratory activities to science learning and yet ignores the views of students who are the focus of learning. In this paper, we reviewed postsecondary school students' experiences in the science laboratories. Students were most concerned about the impact of the laboratory activities and their preferences pointed more towards greater independent, participatory and interactive learning engagements. This review has implied that students should not be left out in science laboratory learning reform efforts and their views about what obtains in the science laboratories should be routinely monitored to inform such reforms.
\end{abstract}

Keywords: science laboratories, laboratory activities, students' views, students' preferences, laboratory learning

\section{INTRODUCTION}

Science laboratory learning activities have frequently come under the spotlight and therefore preoccupied educational researchers. Some have expressed scepticism about the effectiveness of laboratory practical work. For instance, it is believed that laboratory practical work most often leads to limited academic gain (Wieman \& Holmes, 2015). Also, Hodson (1993), referring to teachers added that "much that we provide is illconceived, muddled and lacking in real educational

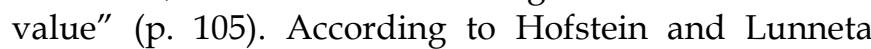
(1982), laboratory learning activities were principally aimed in the 1800s at enhancing technical skills needed for industrial work. However, this has tremendously changed over time. Today, the science laboratory as a learning platform has evolved and represents a complex learning environment with a lot of dimensions that need to be unravelled if progress should be made in science education.

There is overwhelming empirical evidence available in the research literature on the contribution of science laboratories to the attainment of science educational goals. However, most of these omit students' experiences and perspectives. According to Thomas and Meldrum (2018), students' experiences and perceptions about the laboratory is key to understanding the laboratory environment and in making curriculum decisions. In this paper, we argue that students' experiences are critical to the full understanding of the relationship between the pedagogical strategies in the laboratories and the learning outcomes therein. It is the students' views, opinions and perceptions that provide important insights into the influence of the pedagogical changes that are implemented. These insights provide the basis for designing new strategies to inform pedagogies that will enhance students' learning of science inquiry processes.

In students' opinions, the science laboratory includes a place where experiments are conducted to demonstrate the applications of theoretical ideas, a place that affords learners opportunities to put scientific theory into practice (Harman et al., 2016). In one study, students' use of metaphors to describe their perceptions of the physics laboratory generated conceptual categories principal among which was the learning through visual impact, and working in an atelier was the most commonly used metaphor in this category (Aykutlu et al., 2019). Also,

(c) 2022 by the authors; licensee Modestum. This article is an open access article distributed under the terms and conditions of the Creative Commons Attribution License (http://creativecommons.org/licenses/by/4.0/).

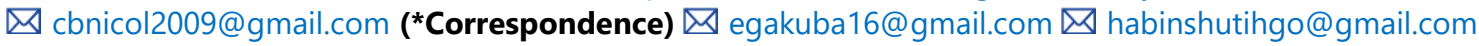




\section{Contribution to the literature}

- As science educators voice scepticisms about the real academic value of science laboratory learning, the research literature shows that students' views have mostly been omitted in this regard.

- To understand the relationship between the pedagogical strategies in science laboratories and their learning outcomes, students' experiences are critical, being at the centre of instruction. Students' insights provide the basis for designing new pedagogical strategies.

- The authors were not aware of any systematic review on the topic for the period under review at the time of writing, as the literature search from various databases did not reveal such.

Burrows et al. (2017) identified students' opinions about categories of learners in a science project-based laboratory as independent researchers, socialites, explorers of mastery and skill.

\section{Aim of the Study}

To address the problem in this study, we embarked on a systematic review of the literature on students' views, perceptions and opinions on science laboratory learning over twelve years; from 2008 to 2020, and the following questions guided the process;

1. What are students' views, opinions and perceptions about learning in the science laboratory?

2. How might these experiences inform current science laboratory instructional practices and future research on laboratory instruction research?

For the purpose of this study, a laboratory refers to a traditional laboratory as well as a virtual laboratory. Also, pre-service teachers are considered students.

\section{METHOD}

The authors were not aware of any systematic review on the topic of this study, and the literature search in five databases for the period under review did not prove otherwise. The authors started the scope search for sources using keywords such as "students' perception of experiments", "laboratory learning", "students' opinions on laboratory", "students' perspectives of laboratory learning". This search was done in the following five electronic databases; ERIC, Google Scholar, ProQuest, EBSCO, and Research4life between June and August 2020. A total of 3,965 sources that were published online were initially gathered. The subject content areas varied and included agriculture, computer science, geology, biology, chemistry, and physics. Initial sources reported studies at all levels of education; elementary schools, high schools, and tertiary institutions.

Filtering of the cumulative sources was done by considering the following reasons for exclusion; duplication of study or titles, non-alignment between the content of the abstract and the construct projected in the

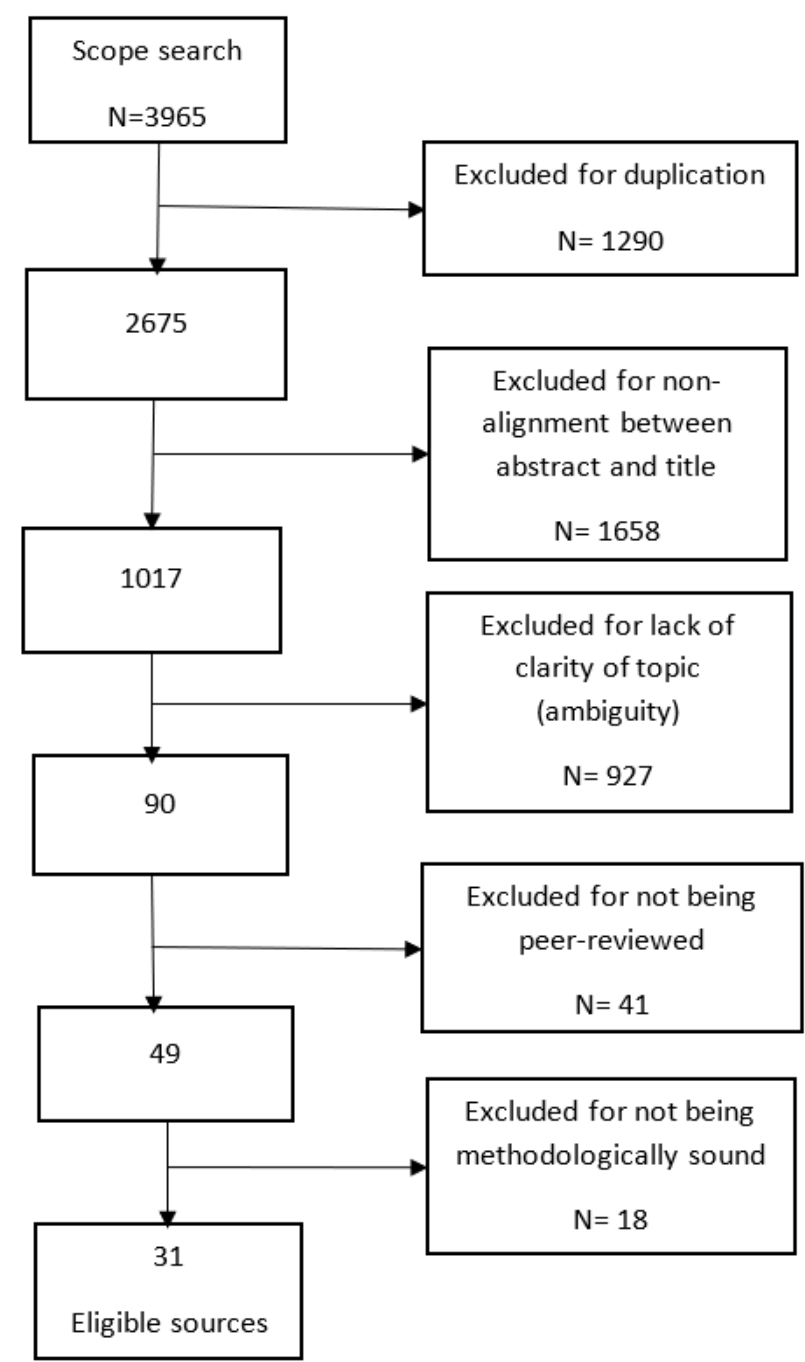

Figure 1. Flow chart of research literature filtering process

title, the lack of clarity of study title, peer-review, methodological soundness, especially the psychometric properties of the data collection instruments. Details of the filtering process are provided in the flow diagram in Figure 1.

In the final stage of the selection of eligible sources, the authors used a methodological quality assessment rubric that was constructed by the corresponding author, and validated by the co-authors and an external auditor. In order to reduce the bias in the judgment of quality and enhance the quality of selected sources, each source was evaluated for construct validity. If a survey was used, a reliability coefficient of at least 0.70 was a 
criterion for inclusion. This process resulted in 31 eligible sources (Appendix A) for thematic analysis.

Therefore, the final selection was based on the following predetermined criteria:

a. If the study subjects were post-secondary school students;

b. If the laboratory studied was in the chemistry, biology, physics, or general science;

c. If the study was peer-reviewed;

d. If the study used an interview or survey;

e. If the topic was not ambiguous, but clearly written; and

f. If the study used sound psychometric properties (statistical or otherwise).

Finally, the full papers were read by each author and the findings (Appendix B) compared for harmonization. Thereafter, the themes "students' perceptions of aims and purposes of laboratory learning, students' perceptions about the effectiveness and impact of laboratory learning and students' preferences in laboratory learning settings" (outcome variables) emerged by consensus among the authors. Every step of the filtering process was conducted by individual authors, followed by a conference for the comparison of outcomes. Where there were disagreements between two authors, the view of the third author reigned supreme. Therefore, every decision in the filtering and selection process was by consensus of the authors' opinions.

\section{RESULTS}

Table 1, Table 2, and Table 3 present the data collected in this study.

Table 1. Included sources of articles by country

\begin{tabular}{lcc}
\hline Country & Number (n) & Percentage (\%) \\
\hline Australia & 2 & 6.45 \\
Australia \& the UK & 1 & 3.23 \\
Canada & 3 & 9.67 \\
Finland & 1 & 3.23 \\
New Zealand & 1 & 3.23 \\
Turkey & 9 & 29.03 \\
UK & 3 & 9.67 \\
USA & 11 & 35.49 \\
Total & 31 & 100.00 \\
\hline
\end{tabular}

Table 2. Subjects in which science laboratory activities were conducted

\begin{tabular}{lcc}
\hline Subject & Number (n) & Percentage (\%) \\
\hline Biology & 4 & 12.90 \\
Chemistry & 11 & 35.48 \\
Biology/Chemistry/Physics & 2 & 6.45 \\
Chemistry \& Physics & 1 & 3.23 \\
General Science & 4 & 12.90 \\
Physics & 9 & 29.03 \\
Total & 31 & 100.00 \\
\hline
\end{tabular}

Table 3. The percentage distribution of the various outcome categories

\begin{tabular}{lcc}
\hline Outcome variable & $\mathrm{n}$ & $\%$ \\
\hline $\begin{array}{l}\text { Students' perceptions of aims \& purposes of } \\
\text { laboratory learning }\end{array}$ & 9 & 20.45 \\
$\begin{array}{l}\text { Students' perceptions about effectiveness \& } \\
\text { impact of laboratory learning }\end{array}$ & 19 & 43.18 \\
$\begin{array}{l}\text { Students' perceptions about anxiety \& } \\
\text { challenges in science laboratory learning process }\end{array}$ & 8 & 18.18 \\
$\begin{array}{l}\text { Students' preferences in laboratory learning } \\
\text { settings }\end{array}$ & 8 & 18.18 \\
\begin{tabular}{l} 
Total \\
\hline
\end{tabular} & 44 & 99.99 \\
\hline
\end{tabular}

\section{Aims and Purposes of Laboratory Learning}

In terms of the purpose of laboratory learning, students' opinions included; the development of practical and scientific process skills, as well as enhancing understanding of the theoretical concepts (Dikmenli, 2009; George-Williams et al., 2018; Hanif et al., 2009), learning science by fun (Aykutlu et al., 2019; Harman et al., 2016; Sadoglu \& Durukan, 2018), effective and meaningful learning (Dikmenli, 2009; Harman et al., 2016), motivation and the development of positive attitude towards science (Dikmenli, 2009), permanent learning and the application of learned concepts (Harman et al., 2016), verification of known scientific theories and principles, conceptual understanding of the nature of science, creation of a link between scientific knowledge and contemporary experiences, and the creation of a link between science, technology, and society (Dikmenli, 2009). With the use of metaphors, students described the purpose of the science laboratory as learning for curiosity, learning by direction and learning by labour (Aykutlu et al., 2019).

Students in George-Williams et al.'s (2018) study stated the purpose as imparting the knowledge of scientific ways of reasoning and the appropriate use of scientific language. Also, students indicated that laboratory instruction is meant to assist them in learning about their learning abilities and developing everyday scientific problem-solving and critical thinking skills (Yildirim, 2016). Interestingly, students held the view that laboratory instruction was meant to help tactile learners more because it afforded them greater opportunities to engage in their preferred styles of learning (Russel \& Weaver, 2008). Also, cited were purposes such as to repeat and reinforce lecture content (Russel \& Weaver, 2008), the enhancement of theoretical understanding, development of practical skills, gaining of laboratory experience (George-Williams et al., 2018), and preparation for the workforce and development of transferable skills (Burrows et al., 2017). However, a section of the students' included the verification of scientific theories and laws (Dikmenli, 2009). 


\section{The Effectiveness and Impact of Laboratory Learning}

Impact was expressed in the cognitive, affective and psychomotor domains. Students stated improvement in their conceptual understanding of science through laboratory exploration (Moozeh et al., 2019; Priest et al., 2014; Whelan et al., 2015) and level of engagement and interaction (Goldina \& Barattini, 2018). Concerning video-based techniques, students rated the level of inquiry as very low but still valued the educational short videos and the majority acknowledged that it was a new experience for them.

The impact of the laboratory experiments also translated into affective attributes as students indicated that they enjoyed the experiments (George-Williams et al., 2018; Henige, 2011; Horsley \& Moeed, 2018), and became motivated and acquired attitudinal change towards science (Chatterjee et al., 2009; Tartar, 2012; Uyulgan \& Akkuzu, 2018; Wright, 2012). Students liked the station-based teaching approach because it made learning less stressful and made shy students more comfortable to ask questions (Goldina \& Baratinni, 2018). Thomas and Meldrum (2018) reported a significant positive effect of laboratory instruction on students' perception of their learning environment. However, Karacop and Diken (2017) realized that there was no significant difference in students' opinions regarding the Jig-saw cooperative approach and the confirmatory approach to laboratory instruction. On the psychomotor front, students realized enhancement in experimental design and laboratory skills (Galloway \& Bretz, 2016; Koretrsky et al., 2011; Tartar, 2012; Yildirim, 2016) as well as communication skills (Whelan et al., 2015).

\section{Anxieties and Challenges in the Science Laboratory Learning Process}

Students' anxieties included the lack of synchronization between the classroom course content and laboratory topics, vague instructions, malfunctioning equipment and the lack of skills in data analysis (Deacon \& Hajek, 2011). Therefore, laboratory experiments were confusing and students expressed fear of making mistakes (Sneddon et al., 2009). In the inquirybased instructional method, students complained about the lack of structure and complete guidance (Henige, 2011). Students performed laboratory experiments without a clear sense of the purpose of the activity and very few demonstrated knowledge of the purpose of the experiments. Students' high expectations that laboratory practicals would be aligned with the lecture contents were not met (Deacon \& Hajek, 2011). Also, students experienced great challenges with the presentation of data in graphs in addition to the lack of understanding of units conversion (Berber, 2013).

For cooperative learning, students struggled in their groups with what to do in their assigned roles, and team roles did not help them complete the laboratory task efficiently and promptly. Instead, it deterred their progress because they were confused and wasted a lot of time determining what every member was supposed to do (Ott et al., 2018). Whelan et al. (2015) highlighted the lack of appropriate instructions and feedback from instructors. Students recounted their experiences in being rushed into completing the procedures to be able to write laboratory reports. Therefore, the focus was shifted from conceptualizing the science behind the experiment to strictly following the procedures (Galloway \& Bretz, 2016). Besides, insufficient assessment in small group class assignments was raised (Whelan et al., 2015). Security and fear of dangerous chemicals were also reported (Priest et al., 2014). Moozeh et al. (2019) also reported students' dissatisfaction with the use of laboratory manuals, which they said did not provide detailed instructions or descriptions of experiments.

\section{Students' Preferences in Laboratory Instruction}

Students' opinions were divided on the preference for virtual or traditional physical laboratory learning. Some students preferred virtual experiments and simulated teaching methods to the traditional wet laboratory one because they could progress with the experiments at their pace; they could stop to review the procedures and continue at will. Students who preferred the traditional wet laboratory teaching method cited the advantage of working in groups and immediate access to the instructor (Crandall et al., 2015; Leung et al., 2016). Also, they preferred written instructions in laboratory manuals (Chatterjee et al., 2009). They enjoyed doing the high-level inquiry experiments more than the low-level inquiry (Henige, 2011) and said that the pre-laboratory modules helped them more than did laboratory manuals in understanding the concepts (Moozeh et al., 2019).

Ott et al. (2018) reported that for the cooperative learning groups, students indicated their highest preference for the role of the data recorder among rotationally assigned roles. Besides they found strength from their peers since they did not feel confident performing the tasks alone. Also, students were attracted to the video-based laboratory instructional approach (Moozeh et al., 2019). The majority of the students preferred that laboratory teaching assistants offer more guidance in carrying out experiments to make them more comfortable (Sandstrom et al., 2014; Sneddon et al., 2009). These students indicated that they would want to design and conduct their experiments with increased guidance (King et al., 2016).

\section{DISCUSSION OF FINDINGS}

Between 2008 and 2020, students' perspectives on science laboratory learning were investigated in peerreviewed sources the most in the USA (Table 1), where 
nearly a third (31.43\%) of all eligible sources in this review came from. This result might not be unconnected with the importance that the USA's science education places on learners' perspectives in educational reform efforts. The findings in this study reflect students' say about laboratory learning in core science subjects, with chemistry being the most represented $(35.48 \%)$, followed by physics $(29.03 \%)$. This implies that the sample of eligible sources considered in this review contained laboratory investigations in chemistry the most. In respect of the four outcome variables in Table 3, which were thematically generated, the matter that amounts to the most concern in students' opinions and views is the effectiveness and impact of laboratory learning, which accounts for $43.18 \%$, followed by the aims and purposes of laboratory learning $(20.45 \%)$. Students made the least mention about anxiety (18.18\%) and preferences $(18.18 \%)$. Notwithstanding, the fact that students have demonstrated their greatest concern to be the impact of the activities in laboratory sessions somewhat places importance on the need for routinely monitoring laboratory work and gauging students' views on reform strategies. Their experiences of numerous anxieties and challenges are reminiscent of the fears and scepticism expressed by some science educators about the potential of laboratory activities in enhancing meaningful learning.

There are a lot of expectations for the results of the laboratory activities, which may affect students' notion of the purpose of the science laboratory. Students' collective views of the aims and purposes of laboratory learning reported in this paper go beyond the scope of just verifying scientific laws and essentially agree with the findings of previous studies. For instance, Hofstein and Lunetta (2004) report the aims and purpose of laboratory learning as consisting; arousal of students' interests and enhancement of their motivation, while McDonnel et al. (2007) found the purposes to be; bringing meaning into the learning process by developing cognitive and analytical skills and making the links between life and science interesting to learners.

The students' views also mirror the National Science Educational Standards' goals for inquiry active learning (NRC, 2006), which highlights students' understanding of the nature of science, enhancement of conceptual understanding and scientific reasoning, motivation towards science and development of practical and social skills. Even so, Trumper (2003) argues that the laboratory should prioritize the teaching of skills and not the nature of science or scientific concepts. However, the views expressed by students corroborate the argument by Aufschnaiter and Aufschnaiter (2007) that laboratory instruction should be targeted at the enhancement and development of conceptual understanding in addition to bridging the gap between theory and practice.

Additionally, students' perspectives in this paper include interesting new insights. Whereas individualized laboratory demonstrations may not be designed to solely help a few learners, students claim that kinesthetic learners stand to benefit more as it affords them more opportunities to engage in their preferred style of learning. Students think that imparting the knowledge of scientific ways of reasoning and the appropriate use of scientific language could be a plausible rationale for the laboratory components and activities in science (George-Williams et al., 2018). The consistency of students' perspectives on the aims of laboratory learning with the views of prominent science educators is suggestive of a need for a shift towards viewing students as partners in the efforts towards the building of a better science community.

Both experience and research have taught us that the environment has an important influence on the success or otherwise of a learning process. As stated by Lewin (1936) cited in Fraser (2012), human behaviour is dependent on both the environment and the interaction of the individual in that environment. The laboratory learning environment has largely been reported in the literature to depict an apprenticeship model, where learners follow a step-by-step procedure after their laboratory instructor or a laboratory manual. This narrows the opportunity and freedom that should be afforded to students in trying out their inquiry techniques, where they make errors, learn from those errors and make learning more interesting and permanent (Hofstein \& Kind, 2012; Hofstein \& Lunetta, 2004). In this study, significant positive learning experiences are reported to accompany changes in students' learning environment as exemplified by the inquiry-based method (Thomas \& Meldrum, 2018), the cooperative jig-saw technique (Karcop \& Diken, 2017), and the station-based teaching approach by Goldina and Barattini (2018). This is corroborated by the findings of Yildirim (2016) who observed between $50 \%$ and $74 \%$ of students expressing that laboratory experiments enhanced key competencies in learners including learning, problem-solving and critical thinking. In all of the aforementioned findings, students demonstrated the relevance of laboratory activities in learning.

Of particular interest is the students' comparative rating of laboratory demonstrators on the levels of preparedness for which the peer demonstrators had $8 \%$ higher scores than PhD student demonstrators (Braun \& Kirkup, 2016). This might mean that students have a greater inclination to work with their peers as laboratory instructors. Many studies have established the varying strengths of correlation between learners' expressed attitudes and academic achievements (Osborne et al., 1998). Freedman (1997) realized that hands-on experiences promote learners' attitudes towards science, which in turn influences academic achievement. Based on this observation, it may be plausible to infer that students' attitudes are a good predictor of academic excellence. 
Clear team members' roles in a cooperative learning environment is a fundamental requirement if learning must be meaningful. In Ott et al.'s (2018) investigation, students had mixed feelings about the benefit of the team roles to individual and group learning. Students generally cited greater productivity, development of social skills and team spirit as achievements in the exercise. In support of the cooperative learning technique, students in Whelan et al.'s (2016) study also believed that facilitated active learning yields a greater academic gain than independent learning. Besides, Springer et al. (1999) found that students demonstrate more positive attitudes towards the subject content materials if they are organized in small groups. Students in this review were enthused by experiments and described as fun, the mixing of two or more chemical substances in chemistry and the dissection experiments in biology (Horsley \& Mooed, 2018). The experiments helped students to learn the science concepts as they demonstrated this in their long term retention of learned content. Therefore, for cooperative working groups, students in this review were divided on their support for group work by their indication of advantages of the two approaches.

Eliciting students' views on what constitutes their fears and anxieties in the science laboratory should be seen as key to attaining academic gains as are the methods of instruction. A more noticeable challenge was associated with the use of multimedia in laboratory instructions. One such study conducted by Priest et al. (2014) reported the lack of familiarity in the use of the technique. Most times, the vast nature of the curriculum and teachers' deficiency in pedagogical and content knowledge compound the problems of the use of technology in teaching (Thornton \& Sokoloff, 1990). Safety and security in the light of the fear of dangerous chemicals have been a concern to students in chemistry laboratory work. As suggested by Harman et al. (2016), there should be visible signs to direct students in the laboratory for any accidents that might occur. The authors also suggest that it might be a good idea for students to be informed in advance about the equipment and chemical substances that they will use in the laboratory. This review has revealed that most students equate preparation for laboratory sessions with reading their laboratory manuals. However, it seems reasonable to think that seeking theoretical information on the subject of the activities from textbooks and other sources in addition to mastering the procedures in the laboratory manuals would better prepare students in advance of experimentation.

Pre-laboratory activities should be designed to not only motivate students but also trigger their thought processes about the relevance and purpose of the upcoming laboratory activity. Students can also prepare for the laboratory by identifying the main theoretical ideas in the experiment, reading those underlying concepts from textbooks. This might immerse students into the experiments more and thus provide them with informed justifications for the activities.

Instructions that accompany tasks and assignments can either ease or confound learning. Students were challenged with clarity of instructions and they realized that this was key to carrying out the experimental procedures. Beyond the instructions, instructors could also model the intended action in the procedures with sufficient illustrations. This will serve to complement the clarity in instructions. According to Tsai (2003), having clearer instructions for students' guidance in the procedures and use of supportive equipment is crucial to the attainment of quality results in the science laboratory. Amidst the challenges, students in this study realize the importance of science laboratory work. Evidence of this is seen in their demonstration of high expectations about the need for the laboratory practical work to be aligned with, and complement the lecture content. However, the high cost of laboratory supplies and the time to be dedicated to laboratory instruction can sometimes lead to not only non-alignment of the classroom and laboratory instructional contents, but the total omission of the laboratory components of science courses in the curriculum (Carnduff \& Reid, 2003).

Students' who were involved in inquiry types of activities indicated the importance of group work and group member contribution to the achievement of the general goal of the activity. These students were given a wide scope of freedom for exploration and critical analysis of the experiments. They were made to design their experiments amidst challenges. They also experienced challenges that stretched their critical thinking and reasoning, especially with partial guidance.

Students' preferences in this study point towards more freedom, greater autonomy and active engagement, which they indicated to enjoy in the learning process: this probably explains why they liked the inquiry-based and innovative teaching techniques. However, the absence of a total dislike for either the traditional or virtual and simulated laboratory approach is suggestive of the need for a combination of both approaches into science laboratory learning in the future. This may meet the affective learning needs of learners, which is undoubtedly related to the cognitive and psychomotor learning gains. In the cooperative learning groups, they preferred the role of data recorder most and the researcher the least, based on the rigour involved in executing the roles (Ott et al., 2018). Guided and high-level inquiry instruction appealed to the students more than an open inquiry. This might be due to their attribution of higher value and importance to partial guidance than non-guidance in their experience. Besides, the fact that the analysis of data in the guided inquiry approach stretched their thinking abilities might have led them into believing that they learned more with high-level inquiry instruction. Students are not alone in 
their preference for guided inquiry over open inquiry. The open inquiry, which requires learners total freedom and autonomy to explore scientific concepts unguided, has been challenged by a section of scholars. For instance, Blanchard (2010) argues that its high demands for sufficient prior knowledge, skills and experience in scientific inquiry, may render it non-applicable in most instances. This high demand can constitute cognitive overload for learners, a situation, which can impair learning. For this reason, Settlage (2007) described it as a highly impracticable level of inquiry for amateurs.

The fact that students liked the high-level guided inquiry approach that did not negatively affect their motivation but led to a lower academic gain, demonstrates a complex nature of the relationship between students' preferred teaching methods and academic achievement. Therefore, a highly rated teaching strategy by students does not always translate into meaningful learning. This is at variance with a generally held notion that anything tending to arouse students' interest in science practical work constitutes a means of motivating them, leading to academic success and the achievement of set learning goals. However, in many cases in this study, there was little evidence of learning although students enjoyed the practical activities. Although Landis and Reschly (2013) conclude that students will become bored and lose out on the lesson if they don't appreciate and get motivated in the classroom especially at the beginning, Taber (2007) cautioned that irrespective of students' appreciation for the practical activities, there is a need for them to demonstrate a high level of cognitive achievement. There is therefore a need for an in-depth study to prove learning gains beyond students' approval of a teaching approach.

\section{CONCLUSIONS AND IMPLICATIONS}

This review set out to examine students' views, opinions and perspectives of laboratory learning and the implications that these would have on current science laboratory practices as well as science education research. This review informs existing literature that most studies of students' perspectives on laboratory learning in the last twelve years have been carried out in the USA, and activities in chemistry have dominated. Among topics for reflection in the science laboratories, students are most interested to talk about the effectiveness and impact of learning. Therefore, they took a keen interest in and demonstrated sufficient knowledge of the aims and purposes of laboratory learning, effectiveness or impact, challenges and anxieties, as well as their preferences in laboratory learning activities.

This has an important implication on the design of laboratory activities. Students should hold a major stake in the design of laboratory activities because their opinions and perspectives of learning are related to the attainment of affective and psychomotor goals in their learning. However, the correlation between the affective and cognitive goals remains inconclusive as far as the analyses have proved. Therefore, improvement in the science laboratory learning would require a more careful examination with respect to the relevance of activities, and students' impressions of the learning process. Routine empirical research should be done to inform needed reforms in science laboratory education. As long as students form the right opinions about activity in the laboratory, the learning becomes intrinsically motivational and might lead to greater cognitive and psychomotor gains.

Views on teaching methods largely favour the high level inquiry, innovative and inquiry teaching approaches that offer greater guidance including cooperative jig-saw, station-based and video-based approaches. Students enjoy autonomy and independence while carrying out experiments and prefer written instructions to accompany experiments. Although students appreciate cooperative groups, instructions on assigned roles may need to be complemented by modelling instructions for greater clarity. Students are wary about the non-alignment of the classroom instructional materials with the laboratory content for reinforcement of learning. Also, insufficient time to complete the activities and the safety of laboratory chemicals are a great concern. Multi-media techniques promise a lot of benefits for use in the laboratories, however, mastery of the use of these technologies represents a major challenge. Therefore, professional development efforts for instructors must include training in the use of these technologies in laboratory instruction. Although some students will always demonstrate good performance on laboratory tasks amidst challenges, the obvious thing to do is to identify these challenges by way of empirical research that solicits their views and thereafter, incorporates these and their suggestions into a broader plan for improvement. Incorporating students' preferred styles of learning into the lesson design will improve their motivation and possibly, performance rate. This requires a paradigm shift in the way laboratory lessons are designed.

Author contributions: All authors have sufficiently contributed to the study, and agreed with the results and conclusions.

Funding: This research was funded by the African Centre of Excellence for Innovative Teaching and Learning Mathematics and Science (ACEITLMS), College of Education, University of Rwanda. Declaration of interest: No conflict of interest is declared by authors.

\section{REFERENCES}

Aykutlu, I., Bezen, S., \& Bayrak, C. (2019). An examination of pre-service teachers' metaphorical perceptions concerning physics lab applications. 
Journal of Faculty of Education, 8(1), 32-53. https:// doi.org/10.14686/buefad.463841

Berber, N. C. (2013). Anxieties, preferences, expectations and opinions of pre-service teachers related to physics laboratory. Educational Research and Reviews, 8(15), 1220-1230.

Blanchard, M. R., Southerland, S. A., Osborne, J. W., Sampson, V. D., Annetta, L. A., \& Granger, E. M. (2010). Is inquiry possible in light of accountability? A quantitative comparison of the relative effectiveness of guided inquiry and verification laboratory instruction. Science Education, 94(4), 577616. https:// doi.org/10.1002/sce.20390

Braun, M., \& Kirkup, L. (2016). Non-physics peer demonstrators in undergraduate laboratories: A study of students' perceptions. European Journal of Physics, 37(1), 1-9. https://doi.org/10.1088/ 01430807/37/1/015703

Burrows, N. L., Nowak, M. K., \& Mooring, S. R. (2017). Students' perceptions of a project-based organic chemistry laboratory environment: A phenomenographic approach. Chemistry Education Research and Practice, 18(4), 811-824. https:/ / doi.org /10.1039/C7RP00064B

Carnduff, J., \& Reid, N. (2003). Enhancing undergraduate chemistry laboratories: Pre-laboratory and postlaboratory exercises, examples and advice. Royal Society of Chemistry.

Chatterjee, S., Williamson, V. M., McCann, K., \& Peck, M. L. (2009). Surveying students' attitudes and perceptions toward guided-inquiry and openinquiry laboratories. Journal of Chemical Education, 86(12), 1427-1432. https://doi.org/10.1021/ ed086p1427

Crandall, P. G., O'Bryan, C. A., Killian, S. A., Beck, D. E., Jarvis, N., \& Clausen, E. (2015). A comparison of the degree of student satisfaction using a simulation or a traditional wet lab to teach physical properties of ice. Journal of Food Science Education, 14(1), 24-29. https:// doi.org/10.1111/1541-4329.12049

Deacon, C., \& Hajek, A. (2011). Student perceptions of the value of physics laboratories. International Journal of Science Education, 33(7), 943-977. https:/ / doi.org/10.1080/09500693.2010.481682

Dikmenli, M. (2009). Biology student teachers' ideas about purpose of laboratory work. Asia-Pacific Forum on Science Learning and Teaching, 10(2), 1-14.

Fraser, B. J. (2012). Classroom learning environments: Retrospect, context and prospect. In B. J. Fraser, K. G. Tobin, \& C. J. McRobbie (Eds.), Second international handbook of science education, (pp. 11911239). Springer. https://doi.org/10.1007/978-14020-9041-7_79

Freedman, M. (1997). Relationship among laboratory instruction, attitude toward science, and achievement in science knowledge. Journal of Research in Science Teaching, 34(4), 343-357. https:// doi.org/10.1002/(SICI)1098-2736(199704) 34:4\%3C343:AID-TEA5\%3E3.0.CO;2-R

Galloway, K. R., \& Bretz, S. L. (2015). Video episodes and action cameras in the undergraduate chemistry laboratory: Eliciting student perceptions of meaningful learning. Chemistry Education Research and Practice, 17(1), 139-155. https://doi.org/ 10.1039/C5RP00196J

George-Williams, S. R., Ziebell, A. L., Kitson, R. R. A., Coppo, P., Thompson, C. D., \& Overton, T. L. (2018). 'What do you think the aims of doing a practical chemistry course are?' A comparison of the views of students and teaching staff across three universities. Chemistry Education Research and Practice, 19(2), 463-473. https://doi.org/10.1039/ C7RP00177K

Goldina, A., \& Barattini, D. (2018). Exploring student perceptions of a station-based teaching approach in the human anatomy and physiology laboratory. HAPS Educator, 22(1), 61-68. https://doi.org/10. 21692/haps.2018.007

Hanif, M., Sneddon, P. H., Al-Ahmadi, F. M., \& Reid, N. (2009). The perceptions, views and opinions of university students about physics learning during undergraduate laboratory work. European Journal of Physics, 30(85), 85-96. https://doi.org/10.1088/ 0143-0807/30/1/009

Harman, G., Cokelez, A., Dal, B., \& Alper, U. (2016). Preservice science teachers' views on laboratory applications in science education: The effect of a two-semester course. Universal Journal of Educational Research, 4(1), 12-25. https://doi.org/ 10.13189/ujer.2016.040103

Henige, K. (2011). Undergraduate student attitudes and perceptions toward low- and high-level inquiry exercise physiology teaching laboratory experiences. Advances in Physiology Education, 35(2), 197-205. https:// doi.org/10.1152/advan.00086.2010

Hodson, D. (1993). Re-thinking old ways: Towards a more critical approach to practical work in school science. Studies in Science Education, 22(1), 85-142. https:// doi.org/10.1080/03057269308560022

Hofstein, A., \& Kind, P. M. (2012). Learning in and from science laboratories. In B. J. Fraser, K. G. Tobin, \& C. J. McRobbie (Eds.), Second international handbook of science education (pp. 189-207). Springer. https://doi.org/10.1007/978-1-4020-9041-7_15

Hofstein, A., \& Lunetta, V. N. (1982). The role of the laboratory in science teaching: Neglected aspects of research. Review of Educational Research, 52(2), 201217. https:/ / doi.org/10.2307/1170311 
Hofstein, A., \& Lunetta, V. N. (2004). The laboratory in science education: Foundations for the twenty-first century. Science Education, 8(1), 28-54. https:/ / doi.org/10.1002/sce.10106

Horsley, J., \& Moeed, A. (2018). "Inspire me"-Highability students' perceptions of school science. Science Education International, 29(3), 163-173. https:/ / doi.org/10.33828/sei.v29.i3.4

Karacop, A., \& Diken, E. H. (2017). The effects of jigsaw technique based on cooperative learning on prospective science teachers' science process skill. Journal of Education and Practice, 8(6), 86-97.

King, N., Touw, T. V., Spowart, L., \& Lawlor, C. (2016). A scoping study investigating student perceptions towards inquiry-based learning in the laboratory. European Journal of Science and Mathematics Education, 4(3), 305-314. https://doi.org/10.30935/ scimath $/ 9472$

Koretsky, M., Kelly, C., \& Gummer, E. (2011). Student perceptions of learning in the laboratory: Comparison of industrially situated virtual laboratories to capstone physical laboratories. Journal of Engineering Education, 100(3), 540-573. https://doi.org/10.1002/j.2168-9830.2011.tb000 26.x

Landis, R. N., \& Reschly, A. L. (2013). Reexamining gifted underachievement and dropout through the lens of student engagement. Journal for the Education of the Gifted, 36(2), 220-249. https://doi.org/10. $1177 / 0162353213480864$

Leung, A. C. K., Terrana, A., \& Jarzak, S. (2016). Students' opinions on the educational values of physics laboratories: A cross-sectional survey. Canadian Journal of Physics, 94(3), 913-919. https://doi.org/10.1139/cjp-2016-0358

McDonnel, C., O'Connor, C., \& Seery, M. K. (2007). Developing practical chemistry skills by means of student-driven problem based learning miniprojects. Chemistry Education Research and Practice, 8(2), 130-139. https://doi.org/10.1039/B6RP900 $26 \mathrm{G}$

Moozeh, K., Farmer, J., Tihanyi, D., Nadar, T., \& Evans, G. J. (2019). A prelaboratory framework toward integrating theory and utility value with laboratories: Student perceptions on learning and motivation. Journal of Chemical Education, 96(8), 1548-1557. https://doi.org/10.1021/acs.jchemed. 9b00107

Natinal Research Council. (1996). National science education standards. National Academy Press.

Osborne, J., Simon, S., \& Collins, S. (2003). Attitudes towards science: A review of the literature and its implications. International Journal of Science Education, 25(9), 1049-1079. https://doi.org/10. $1080 / 0950069032000032199$
Ott, L. E., Kephart, K., Stolle-McAllister, K., \& LaCourse, W. R. (2018). Students' understanding and perceptions of assigned team roles in a classroom laboratory environment. Journal of College Science Teaching, 47(4), 83-91. https://doi.org/10.2505/4/ jcst18_047_04_83

Priest, S. J., Pyke, S. M., \& Williamson, N. M. (2014). Student perceptions of chemistry experiments with different technological interfaces: A comparative study. Journal of Chemical Education, 91(11), 17871795. https://doi.org/10.1021/ed400835h

Russell, C. B., \& Weaver, G. (2008). Student perceptions of the purpose and function of the laboratory in science: A grounded theory study. International Journal for the Scholarship of Teaching and Learning, 2(2), 1-14. https://doi.org/10.20429/ijsotl.2008. 020209

Sadoglu, G. P., \& Durukan, U. G. (2018). Determining the perceptions of teacher candidates on the concepts of science course, science laboratory, science teacher and science student via metaphors. International Journal of Research in Education and Science, 4(2), 436-453. https://doi.org/10.21890/ ijres. 428260

Sandström, N., Ketonen, E., \& Lonka, K. (2014). The experience of laboratory learning-How do chemistry students perceive their learning environment? The European Journal of Social and Behavioural Sciences, 11(4), 1613-1625. https:/ / doi.org/10.15405/ejsbs.144

Settlage, J. (2007). Demythologizing science teacher education: Conquering the false ideal of open inquiry. Journal of Science Teacher Education, 18(4), 461-467. https://doi.org/10.1007/s10972-0079060-9

Sneddon, P. H., Slaughter, K. A., \& Reid, N. (2009). Perceptions, views and opinions of university students about physics learning during practical work at school. European Journal of Physics, 30(5), 1119-1129. https://doi.org/10.1088/0143-0807/30 /5/018

Springer, L., Stanne, M. E., \& Donovan, S. S. (1999). Effects of small-group learning on undergraduates in science, mathematics, engineering, and technology: A meta-analysis. Review of Educational Research, 69(1), 21-51. https://doi.org/10.3102/ 00346543069001021

Taber, K. S. (2007). Science education for gifted learners. Routledge. https:/ / doi.org/10.4324/9780203962046

Tatar, N. (2012). Inquiry-based science laboratories: An analysis of preservice teachers' beliefs about learning science through inquiry and their performances. Journal of Baltic Science Education, 
11(3), 248-266. https://www.researchgate.net/ publication/288284135

Thomas, G., \& Meldrum, A. (2018). Students' perceptions of changes to the learning environments of undergraduate physics laboratories: An empirical study. Interactive Technology and Smart Education, 15(4), 165-180. https:/ / doi.org/10.1108/ITSE-10-2017-0045

Thornton, R. K., \& Sokoloff, D. R. (1990). Learning motion concepts using real-time microcomputerbased laboratory tools. American Journal of Physics, 58(9), 858-867. https:// doi.org/10.1119/1.16350

Trumper, R. (2003). The physics laboratory-A historical overview and future perspectives. Science $\mathcal{E}$ Education, 12(7), 645-670. https:/ / doi.org/10.1023/ A:1025692409001

Tsai, C. (2003). Taiwanese science students' and teachers' perceptions of the laboratory learning environments: Exploring epistemological gaps. International Journal of Science Education, 25(7), 847860. https:// doi.org/10.1080/09500690305031

Uyulgan, M. A., \& Akkuzu, N. (2018). Educational short videos to utilize in the biochemistry laboratory: Opinions of university students. Journal of Baltic Science Education, 17(3), 496-510. https://doi.org/ $10.33225 /$ jbse/18.17.496 von Aufschnaiter, C., \& von Aufschnaiter, S. (2007). University students' activities, thinking and learning during laboratory work. European Journal of Physics, 28, S51-S60. https://doi.org/10.1088/ 0143-0807/28/3/S05

Weiman, C., \& Holmes, N. G. (2015). Measuring the impact of an instructional laboratory on the learning of introductory physics. American Journal of Physics, 83(11), 972-978. https://doi.org/ $10.1119 / 1.4931717$

Whelan, A., Leddy, J. J., Mindra, S., Hughes, J. D., ElBaily, S., \& Ramnanan, C. J. (2016). Students' perceptions of independent versus facilitated small group learning approaches to compressed medical anatomy education. Anatomical Science Education, 9(1), 40-51. https:/ / doi.org/10.1002/ase.1544

Wright, S. J. (2012). Student perceptions of an upperlevel, undergraduate human anatomy laboratory course without cadavers. Anatomical Sciences Education, 5(3), 146-157. https://doi.org/10.1002/ ase. 1265

Yildirim, N. (2016). Opinions of pre-service classroom teachers towards laboratory using in science instruction and their preferences towards laboratory approaches. Journal of Education and Training Studies, 4(3), 208-222. https://doi.org/10. $11114 /$ jets.v4i3.1304 


\section{APPENDIX A}

\section{List of Eligible Sources that Met the Inclusion Criteria}

\begin{tabular}{lll}
\hline & Author(s) & Year Title \\
\hline 1 & Aykutlu et al. & $\begin{array}{c}2019 \text { An examination of pre-service teachers' metaphorical perceptions concerning physics lab } \\
\text { applications }\end{array}$
\end{tabular}

2 Berber

2013 Anxieties, preferences, expectations and opinions of pre-service teachers related to physics laboratory

3 Braun and Kirkup 2016 Non-physics peer demonstrators in undergraduate laboratories: A study of students' perceptions

4 Burrows et al. 2017 Students' perceptions of a project-based organic chemistry laboratory environment: A phenomenographic approach

5 Chatterjee et al. 2009 Surveying students' attitudes and perceptions toward guided-inquiry and open-inquiry laboratories

6 Crandall et al. 2015 A comparison of the degree of student satisfaction using a simulation or a traditional wet lab to teach physical properties of ice

7 Deacon and Hajek 2011 Student perceptions of the value of physics laboratories

8 Dikmenli 2009 Biology student teachers' ideas about the purpose of laboratory work

9 Galloway and 2015 Video episodes and action cameras in the undergraduate chemistry laboratory: Eliciting student Bretz

10 George-Williams et al.

11 Goldina and Barattini

12 Hanif et al.

13 Harman et al. perceptions of meaningful learning

2018 'What do you think the aims of doing a practical chemistry course are?' A comparison of the views of students and teaching staff across three universities.

2018 Exploring student perceptions of a station-based teaching approach in the human anatomy and physiology laboratory

2009 The perceptions, views and opinions of university students about physics learning during undergraduate laboratory work

2016 Pre-service science teachers' views on laboratory applications in science education: The effect of a two-semester course

14 Henige

15 Horsley and Moeed

16 Karacop and Diken

17 King et al.

18 Leung et al.

19 Moozeh et al.

2011 Undergraduate student attitudes and perceptions toward low- and high-level inquiry exercise physiology teaching laboratory experiences

2018 "Inspire me" - High-ability students' perceptions of school science

2017 The effects of jigsaw technique based on cooperative learning on prospective science teachers' science process skill

2016 A scoping study investigating student perceptions towards inquiry-based learning in the laboratory

2016 Students' opinions on the educational value of physics laboratories: A cross-sectional survey

2019 A pre-laboratory framework toward integrating theory and utility value with laboratories: Student perceptions on learning and motivation

20 Ott et al.

21 Priest et al.

22 Russell and Weaver

23 Sadoglu and Durukan

24 Sandström et al.

25 Sneddon et al.

2018 Students' understanding and perceptions of assigned team roles in a classroom laboratory environment

2014 Student perceptions of chemistry experiments with different technological interfaces: A comparative study

2008 Student perceptions of the purpose and function of the laboratory in science: A grounded theory study

2018 Determining the perceptions of teacher candidates on the concepts of science course, science laboratory, science teacher and science student via metaphors

2014 The experience of laboratory learning-How do chemistry students perceive their learning environment?

2009 Perceptions, views and opinions of university students about physics learning during practical work at school.

26 Tatar

27 Thomas and Meldrum

28 Uyulgan and Akkuzu

29 Whelan et al.

30 Wright

31 Yildirim

2012 Inquiry-based science laboratories: An analysis of pre-service teachers' beliefs about learning science through inquiry and their performances

2018 Students' perceptions of changes to the learning environments of undergraduate physics laboratories: An empirical study

2018 Educational short videos to utilize in the biochemistry laboratory: Opinions of university students

2016 Students' perceptions of independent versus facilitated small group learning approaches to compressed medical anatomy education

2012 Student perceptions of an upper-level, undergraduate human anatomy laboratory course without cadavers

2016 Opinions of pre-service classroom teachers towards laboratory using in science instruction and their preferences towards laboratory approaches 


\section{APPENDIX B}

\section{Data from Eligible Articles by Outcome Variables}

\begin{tabular}{lllll}
\hline Author(s) & $\begin{array}{l}\text { No of } \\
\text { students }\end{array}$ Subject $\quad$ Country & Variables of interest & How measured & Key findings
\end{tabular}

Students' views about what constitute the aims \& purposes of laboratory learning

Aykutlu et $46 \quad$ Physics Turkey Pre-service physics Metaphors form

al. (2019)

teachers' perceptions

concerning "physics researchers lab application"

$\begin{array}{llll}\begin{array}{l}\text { Burrows et } \\ \text { al. (2017) }\end{array} & \text { Chemistry } & \text { USA } \\ & & & \\ & & \\ \begin{array}{l}\text { Dikmenli } \\ \text { (2009) }\end{array} & & \text { Biology } & \text { Turkey }\end{array}$

Ways students perceive a projectbased organic chemistry lab
Phenomenology \& Exploring unknown in science semi-structured Cultivating independence interview Practice understanding of concept Social interactions Developing tech skills for future career

Gathering details of lab \& experiments Efficiency \& saving time To verify theories \& principles, learning laboratory techniques, meaningful learning, making abstract concepts concrete, motivation towards science, acquire scientific process skills, create links between scientific knowledge \& daily life, mastery of nature of science, critical thinking skills, create links between science, technology, \& society To develop practical skills, enhance the application of theoretical concepts, \& better understand theoretical concepts To learn practical skills as well as to illustrate theory taught in lectures Providing a medium to improve collaborative work

Effective learning, permanent learning, \& better understanding, faster learning \& learning with fun

al. (2016)

Chemistry

Turkey

laboratory work

activities within \& interviews

degree programs

Undergraduate Survey

students' perceptions, Focus group views, \& opinions interviews about physics learning

during their

Views on concept \& Survey

purpose of laboratory questionnaire

Before \& after

laboratory teaching Observation \& experiment for quality

of learning

Russel and $13 \quad$ General

USA

Students' perceptions Interview To perform procedures, not to learn of purpose of laboratory

(2008)

Science

Sadoglu and 58

Durukan

General

Turkey

Science
Students' concepts of Phenomenology science course, science Students were lab science teachers, \& asked to complete science student using sentences metaphors the theory

To repeat \& reinforce lecture materials

Science course as understanding/discovering life science laboratory as "a place that provides experience \& entertainment", science teacher as "a mentor", science student as "a valuable being" 
Data from Eligible Articles by Outcome Variables (continued)

\begin{tabular}{llllll}
\hline Author(s) & $\begin{array}{l}\text { No of } \\
\text { students }\end{array}$ Subject & Country & Variables of interest & How measured & Key findings \\
\hline $\begin{array}{l}\text { Sneddon et } \\
\text { al. (2009) }\end{array}$ & Physics & UK & $\begin{array}{l}\text { View of } \\
\text { undergraduate } \\
\text { physics students in } \\
\text { relation to their } \\
\text { experiences of } \\
\text { practical physics at } \\
\text { school }\end{array}$ & $\begin{array}{l}\text { Survey } \\
\text { questionnaire \& } \\
\text { interview }\end{array}$ & $\begin{array}{l}\text { Students view practical side of } \\
\text { course as a way they encounter new } \\
\text { matter/concepts in their courses }\end{array}$ \\
& & & \\
& & & & \\
\end{tabular}

Students opinions about the impact of science laboratory learning

\begin{tabular}{lllll}
\hline Braun and 1,700 Physics & Australia Effect of introduction Survey & Compared to PhD demonstrators,
\end{tabular}

Kirkup of non-physics major

(2016)

peer demonstrators

less experienced demonstrators

(peer \& honors students) received

on student perception

of demonstrator-

student interactions in

laboratory

Chatterjee et 703

Chemistry USA

Chemistry USA

al. (2009)

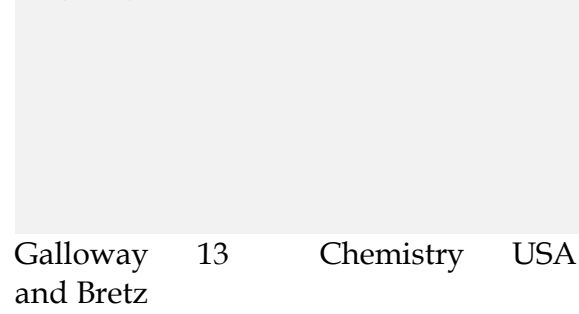

(2016)

George-

3,202

Chemistry

Williams et

al. (2018)

Goldina and 88

Barattini

(2018)

Biology

USA chemistry laboratory

UK

Students' perceptions Survey

$\&$ attitudes toward questionnaire

guided \& open

inquiry-based labs

laboratory

$8 \%$ higher scores in perception of

demonstrator being well prepared to

help in encouraging student to think

deeply about experiment

Students have a more positive attitude toward guided inquiry laboratory than open-inquiry

laboratory

Students believe that they learn more with guided-inquiry

laboratory than open-inquiry laboratory

Students' cognitive \& Video recording \& The laboratory gives students an affective learning interview experiences in undergraduate

cognitive, Questionnaire psychomotor, \& affective expectations of students during laboratory sessions

Survey opportunity to use their hands to physically carry out experiments

Students agreed to statements on survey instrument that aided their meaningful learning

Students also tended to select either neutral, disagree, or strongly disagree to statements that would have a negative impact on their meaningful learning (e.g. I expect to be frustrated)

SBA method was more engaging, interactive, less intimidating, \& learning experience less stressful for students with diverse science backgrounds

It allowed students to feel more comfortable asking questions Although the content was challenging, students in the SBA method felt more positive about their lab experience

Students enjoy HL projects more than LL activity

HL inquiry does not have a negative effect on students' motivation Students perceived that they learned more about physiology principles with LL activity 
Data from Eligible Articles by Outcome Variables (continued)

\begin{tabular}{|c|c|c|c|c|c|c|}
\hline Author(s) & $\begin{array}{l}\text { No of } \\
\text { students }\end{array}$ & Subject & Country & Variables of interest & How measured & Key findings \\
\hline $\begin{array}{l}\text { Horsley and } \\
\text { Moeed } \\
(2018)\end{array}$ & & $\begin{array}{l}\text { Biology, } \\
\text { Chemistry, \& } \\
\text { Physics }\end{array}$ & $\begin{array}{l}\text { New } \\
\text { Zealand }\end{array}$ & $\begin{array}{l}\text { Students' views about } \\
\text { their learning } \\
\text { experiences in science }\end{array}$ & $\begin{array}{l}\text { Questionnaire \& } \\
\text { focus group }\end{array}$ & $\begin{array}{l}\text { Students' enjoyed experiences } \\
\text { Appreciated pedagogy }\end{array}$ \\
\hline $\begin{array}{l}\text { Karacop and } \\
\text { Diken (2017) }\end{array}$ & & $\begin{array}{l}\text { Biology, } \\
\text { Chemistry, \& } \\
\text { Physics }\end{array}$ & Turkey & $\begin{array}{l}\text { Students' opinions } \\
\text { regarding cooperative } \\
\text { learning-based jigsaw } \\
\text { method \& } \\
\text { confirmatory } \\
\text { laboratory method } \\
\text { Differences in terms of } \\
\text { students' science } \\
\text { process skills (jigsaw } \\
\text { \& traditional lab) }\end{array}$ & $\begin{array}{l}\text { Questionnaire } \\
\text { survey in a pre- } \\
\text { test-post-test } \\
\text { design }\end{array}$ & $\begin{array}{l}\text { There was no statistically significant } \\
\text { difference between opinions of the } \\
\text { students regarding applied } \\
\text { laboratory approaches }\end{array}$ \\
\hline $\begin{array}{l}\text { Koretsky et } \\
\text { al. (2011) }\end{array}$ & 111 & Physics & USA & $\begin{array}{l}\text { Students' perceptions } \\
\text { of nature of cognition, } \\
\text { experimental design, } \\
\& \text { ambiguity }\end{array}$ & $\begin{array}{l}\text { Survey } \\
\text { questionnaire }\end{array}$ & $\begin{array}{l}\text { Students show enhanced awareness } \\
\text { of experimental design, greater } \\
\text { references to critical thinking, \& } \\
\text { higher order cognition in virtual } \\
\text { laboratory \& an enhanced awareness } \\
\text { of laboratory protocol in laboratory } \\
\text { Many students indicated an ability to } \\
\text { suspend disbelief \& demonstrate } \\
\text { psychological immersion in the } \\
\text { virtual laboratory project }\end{array}$ \\
\hline $\begin{array}{l}\text { Moozeh et } \\
\text { al. }(2019)\end{array}$ & 89 & Chemistry & USA & $\begin{array}{l}\text { Students' opinions } \\
\text { about anticipated } \\
\text { benefits including } \\
\text { related theory, } \\
\text { procedural } \\
\text { justification, \& } \\
\text { relevance of } \\
\text { experiments in a } \\
\text { prelab module } \\
\text { through multimedia } \\
\text { design }\end{array}$ & $\begin{array}{l}\text { Survey } \\
\text { questionnaire \& } \\
\text { videos }\end{array}$ & $\begin{array}{l}\text { More than } 60 \% \text { of students thought } \\
\text { that prelab modules helped them } \\
\text { understand supportive information } \\
\text { Students also indicated that prelab } \\
\text { modules helped them understand } \\
\text { theory better than laboratory manual } \\
50 \% \text { to } 68 \% \text { of students responded } \\
\text { positively to statements regarding } \\
\text { utility value / relevance justification }\end{array}$ \\
\hline $\begin{array}{l}\text { Priest et al. } \\
(2014)\end{array}$ & 187 & Chemistry & Australia & $\begin{array}{l}\text { Differences in student } \\
\text { perception in } \\
\text { chemistry experiments } \\
\text { conducted by two } \\
\text { different cohorts of } \\
\text { students }\end{array}$ & $\begin{array}{l}\text { Survey } \\
\text { questionnaire }\end{array}$ & $\begin{array}{l}\text { Widespread improvements in } \\
\text { student perceptions of their } \\
\text { laboratory experience were observed, } \\
\text { prominently including reduced } \\
\text { negativity concerning equipment, an } \\
\text { increased perception of } \\
\text { understanding, an increased } \\
\text { perception of simplicity, \& more } \\
\text { positive perceptions of overall } \\
\text { laboratory experience }\end{array}$ \\
\hline $\begin{array}{l}\text { Sneddon et } \\
\text { al. (2009) }\end{array}$ & 500 & Physics & UK & $\begin{array}{l}\text { View of } \\
\text { undergraduate } \\
\text { physics students in } \\
\text { relation to their } \\
\text { experiences of } \\
\text { practical physics at } \\
\text { school }\end{array}$ & $\begin{array}{l}\text { Survey } \\
\text { questionnaire \& } \\
\text { interview }\end{array}$ & $\begin{array}{l}\text { Students felt that experiencing self- } \\
\text { driven experiments prepared them } \\
\text { for inevitable day when there would } \\
\text { not always be written instructions for } \\
\text { work they would be doing }\end{array}$ \\
\hline
\end{tabular}


Data from Eligible Articles by Outcome Variables (continued)

\begin{tabular}{|c|c|c|c|c|c|c|}
\hline Author(s) & $\begin{array}{l}\text { No of } \\
\text { students }\end{array}$ & Subject & Country & Variables of interest & How measured & Key findings \\
\hline Tartar (2012) & 41 & $\begin{array}{l}\text { General } \\
\text { Science }\end{array}$ & Turkey & \multicolumn{2}{|c|}{$\begin{array}{l}\text { Students' beliefs about Interviews \& } \\
\text { learning science observations } \\
\text { through inquiry before } \\
\text { \& after inquiry-based } \\
\text { instruction }\end{array}$} & $\begin{array}{l}\text { Past experiences of students were } \\
\text { effective on beliefs about learning } \\
\text { science through inquiry } \\
\text { The open inquiry science activity in } \\
\text { decision making, discussion, } \\
\text { collaboration, \& interaction were } \\
\text { effective in developing their beliefs } \\
\text { concerning learning science through } \\
\text { inquiry \& increasing their ability to } \\
\text { apply scientific inquiry process }\end{array}$ \\
\hline $\begin{array}{l}\text { Thomas and } \\
\text { Meldrum } \\
(2018)\end{array}$ & & Physics & USA & $\begin{array}{l}\text { Impact, thinking } \\
\text { process, value, \& } \\
\text { appropriateness of a } \\
\text { changed laboratory } \\
\text { environment }\end{array}$ & $\begin{array}{l}\text { Undergraduate } \\
\text { physics laboratory } \\
\text { learning } \\
\text { environment } \\
\text { survey (UPLLES) \& } \\
\text { semi-structured } \\
\text { interviews }\end{array}$ & $\begin{array}{l}\text { Changes had a significant positive } \\
\text { effect on students' perceptions of } \\
\text { their laboratory learning } \\
\text { environments } \\
\text { \& Reforms stimulated "inquiry" } \\
\text { thinking } \\
\text { Large effect sizes \& confirmed } \\
\text { marked changes in students' } \\
\text { perceptions }\end{array}$ \\
\hline $\begin{array}{l}\text { Uyulgan and } \\
\text { Akkuzu } \\
(2018)\end{array}$ & & Chemistry & Turkey & $\begin{array}{l}\text { Students' opinion } \\
\text { about short videos in } \\
\text { biochemistry } \\
\text { laboratory }\end{array}$ & $\begin{array}{l}\text { Semi-structured } \\
\text { interview }\end{array}$ & $\begin{array}{l}\text { Activity interested students \& it was } \\
\text { instructive } \\
\text { Use of videos in laboratory } \\
\text { environment had a positive effect \& } \\
\text { improved students' attitudes \& } \\
\text { interests towards laboratory course } \\
\text { Students stated that educational } \\
\text { video learning activities positively } \\
\text { affected their intrinsic motivation } \\
\text { Educational videos improved } \\
\text { student's communication skills }\end{array}$ \\
\hline $\begin{array}{l}\text { Whelan et al. } \\
\text { (2015) }\end{array}$ & .225 & Biology & Canada & $\begin{array}{l}\text { Students' perceptions } \\
\text { regarding the } \\
\text { comparison between } \\
\text { two small group } \\
\text { learning approaches to } \\
\text { compressed integrated } \\
\text { anatomy education }\end{array}$ & $\begin{array}{l}\text { Quantitative } \\
\text { (Likert-style } \\
\text { questions) \& } \\
\text { interview } \\
\end{array}$ & $\begin{array}{l}\text { Gains in collaboration \& } \\
\text { communication skills Students taught } \\
\text { by facilitated active learning } \\
\text { performed better on practical } \\
\text { examinations }\end{array}$ \\
\hline $\begin{array}{l}\text { Wright } \\
\text { (2012) }\end{array}$ & 30 & Chemistry & USA & $\begin{array}{l}\text { Student reactions to an } \\
\text { upper-level human } \\
\text { anatomy laboratory } \\
\text { course for } \\
\text { undergraduate } \\
\text { students }\end{array}$ & $\begin{array}{l}\text { רurvey } \\
\text { questionnaire }\end{array}$ & $\begin{array}{l}\text { Students embraced the use of models } \\
\text { in the course } \\
\text { It deepened, focused, \& increased } \\
\text { their interest in their learning of } \\
\text { anatomy } \\
\text { Laboratory manual helped them } \\
\text { learn about anatomical models \& } \\
\text { know how to navigate primal } \\
\text { pictures } \\
\text { Students agreed that prelab exercises } \\
\text { made their learning more interesting }\end{array}$ \\
\hline $\begin{array}{l}\text { Yildirim } \\
\text { (2016) }\end{array}$ & 236 & $\begin{array}{l}\text { General } \\
\text { Science }\end{array}$ & Turkey & $\begin{array}{l}\text { Opinions on } \\
\text { laboratory } \\
\text { applications }\end{array}$ & $\begin{array}{c}\text { Survey } \\
\text { questionnaires }\end{array}$ & $\begin{array}{l}\text { Laboratory learning improves } \\
\text { learning skills, consolidates subject } \\
\text { matter, improves self-expression with } \\
\text { group, enhances critical thinking \& } \\
\text { problem solving skills, \& helps in } \\
\text { making associations with daily life } \\
\text { experiences }\end{array}$ \\
\hline
\end{tabular}


Data from Eligible Articles by Outcome Variables (continued)

\begin{tabular}{|c|c|c|c|c|c|c|}
\hline Author(s) & $\begin{array}{l}\text { No of } \\
\text { students }\end{array}$ & Subject & Country & Variables of interest & How measured & Key findings \\
\hline \multicolumn{7}{|c|}{ Students' opinions on their challenges \& anxieties in laboratory learning } \\
\hline \multicolumn{2}{|c|}{ Berber (2013)245 } & Physics & Turkey & $\begin{array}{l}\text { Level of pre-service } \\
\text { teachers' anxieties } \\
\text { about physics } \\
\text { laboratory }\end{array}$ & $\begin{array}{l}\text { Qualitative \& } \\
\text { quantitative } \\
\text { methods \& } \\
\text { semi-structured } \\
\text { interviews with } 20 \\
\text { students }\end{array}$ & $\begin{array}{l}\text { Students had difficulty drawing } \\
\text { graphs, converting units of measure, } \\
\& \text { using laboratory materials } \\
\text { They also had difficulty in } \\
\text { understanding purpose of } \\
\text { experiment }\end{array}$ \\
\hline $\begin{array}{l}\text { Deacon and } \\
\text { Hajek (2011) }\end{array}$ & 168 & Physics & Canada & $\begin{array}{l}\text { Students' perceptions } \\
\text { of value of physics } \\
\text { laboratories }\end{array}$ & Survey & $\begin{array}{l}\text { Lack of synchronization between } \\
\text { course \& laboratory topics, influences } \\
\text { students' ability to successfully } \\
\text { complete laboratory exercise } \\
\text { Waiting for help from TAs, 'vague' } \\
\text { instructions, malfunctioning } \\
\text { equipment, \& lack of familiarity with } \\
\text { data analysis software were problems } \\
\text { taking up precious time in laboratory }\end{array}$ \\
\hline $\begin{array}{l}\text { Galloway } \\
\text { and Bretz } \\
(2016)\end{array}$ & 13 & Chemistry & USA & $\begin{array}{l}\text { Students' cognitive \& } \\
\text { affective learning } \\
\text { experiences in } \\
\text { undergraduate } \\
\text { chemistry laboratory }\end{array}$ & $\begin{array}{l}\text { Video recording/ } \\
\text { interview doing \& } \\
\text { why they were } \\
\text { doing it }\end{array}$ & $\begin{array}{l}\text { Few students discussed learning } \\
\text { chemical ideas while in laboratory, \& } \\
\text { some declared to not learn anything } \\
\text { at all }\end{array}$ \\
\hline $\begin{array}{l}\text { Henige } \\
\text { (2011) }\end{array}$ & 39 & $\begin{array}{l}\text { General } \\
\text { Science }\end{array}$ & USA & $\begin{array}{l}\text { Students reactions to } \\
\text { traditional, cook-book } \\
\text { style, low-inquiry } \\
\text { level (LL) activities, \& } \\
\text { a high-inquiry level } \\
\text { (HL) investigative } \\
\text { project were } \\
\text { compared }\end{array}$ & $\begin{array}{l}\text { Survey } \\
\text { questionnaire }\end{array}$ & $\begin{array}{l}\text { Of students who did not like HL } \\
\text { project, many reported being } \\
\text { uncomfortable with lack of structure } \\
\& \text { guidance }\end{array}$ \\
\hline $\begin{array}{l}\text { Moozeh et } \\
\text { al. (2019) }\end{array}$ & 89 & Chemistry & USA & $\begin{array}{l}\text { Students views about } \\
\text { usefulness of } \\
\text { laboratory manual }\end{array}$ & $\begin{array}{l}\text { Survey } \\
\text { questionnaire \& } \\
\text { videos }\end{array}$ & $\begin{array}{l}\text { Laboratory manual did not usually } \\
\text { provide detailed theory description } \\
\text { or experimental procedure }\end{array}$ \\
\hline $\begin{array}{l}\text { Ott et al. } \\
(2018)\end{array}$ & 20 & $\begin{array}{l}\text { General } \\
\text { Science }\end{array}$ & USA & $\begin{array}{l}\text { Student } \\
\text { understanding \& } \\
\text { perceptions of } \\
\text { assigned team roles in } \\
\text { a classroom laboratory } \\
\text { environment }\end{array}$ & $\begin{array}{l}\text { Survey } \\
\text { questionnaire \& } \\
\text { focus group } \\
\text { interview }\end{array}$ & $\begin{array}{l}\text { Students' understanding of team } \\
\text { roles contradicted somewhat original } \\
\text { descriptions they were given } \\
\text { Students did not perceive roles as a } \\
\text { requirement to obtain team } \\
\text { productivity \& cohesion, given that } \\
\text { many students reported ignoring } \\
\text { roles altogether }\end{array}$ \\
\hline $\begin{array}{l}\text { Sneddon et } \\
\text { al. (2009) }\end{array}$ & 500 & Physics & UK & $\begin{array}{l}\text { Views of } \\
\text { undergraduate } \\
\text { physics students in } \\
\text { relation to their } \\
\text { experiences of } \\
\text { practical physics at } \\
\text { school }\end{array}$ & $\begin{array}{l}\text { Survey } \\
\text { questionnaire \& } \\
\text { interview }\end{array}$ & $\begin{array}{l}\text { Students find laboratory environment } \\
\text { a confusing one \& want to minimize } \\
\text { chance of making mistakes }\end{array}$ \\
\hline $\begin{array}{l}\text { Whelan et al } \\
\text { (2015) }\end{array}$ & .225 & Biology & Canada & $\begin{array}{l}\text { Students' opinion } \\
\text { about adequacy of } \\
\text { time \& assessment }\end{array}$ & $\begin{array}{l}\text { Survey, Likert- } \\
\text { scale, \& interview }\end{array}$ & Lack of sufficient time \& assessment \\
\hline
\end{tabular}


Data from Eligible Articles by Outcome Variables (continued)

\begin{tabular}{|c|c|c|c|c|c|c|}
\hline Author(s) & $\begin{array}{l}\text { No of } \\
\text { students }\end{array}$ & Subject & Country & Variables of interest & How measured & Key findings \\
\hline \multicolumn{7}{|c|}{ Students' opinions about their preferences in laboratory learning } \\
\hline \multicolumn{2}{|c|}{$\begin{array}{l}\text { Chatterjee et } 703 \\
\text { al. (2009) }\end{array}$} & Chemistry & USA & $\begin{array}{l}\text { Students' preference } \\
\text { in guided \& open } \\
\text { inquiry laboratories }\end{array}$ & $\begin{array}{l}\text { Survey } \\
\text { questionnaire }\end{array}$ & $\begin{array}{l}\text { More students preferred guided } \\
\text { inquiry to open inquiry laboratory }\end{array}$ \\
\hline $\begin{array}{l}\text { Crandall et } \\
\text { al. (2015) }\end{array}$ & 48 & Chemistry & USA & $\begin{array}{l}\text { Students' satisfaction } \\
\text { of use of simulation } \\
\text { vs. traditional wet } \\
\text { laboratory to teach } \\
\text { physical properties of } \\
\text { ice }\end{array}$ & $\begin{array}{l}\text { Survey } \\
\text { questionnaire }\end{array}$ & $\begin{array}{l}\text { There was a general preference of } \\
\text { simulated laboratory over traditional } \\
\text { wet laboratory. Students who } \\
\text { preferred simulated laboratory felt } \\
\text { they could move at their own pace \& } \\
\text { were able to stop \& review } \\
\text { simulation to understand concepts } \\
\text { more clearly. Traditional wet } \\
\text { laboratory proponents liked working } \\
\text { in groups \& having immediate access } \\
\text { to instructors }\end{array}$ \\
\hline $\begin{array}{l}\text { Henige } \\
(2011)\end{array}$ & 39 & $\begin{array}{l}\text { General } \\
\text { Science }\end{array}$ & USA & $\begin{array}{l}\text { Students reactions to } \\
\text { traditional, cookbook } \\
\text { style, low-inquiry } \\
\text { level (LL) activities, \& } \\
\text { a high-inquiry level } \\
\text { (HL) investigative } \\
\text { project }\end{array}$ & $\begin{array}{l}\text { Survey } \\
\text { questionnaire }\end{array}$ & $\begin{array}{l}\text { Students enjoyed HL projects more } \\
\text { than LL activity Most students liked } \\
\text { HL project, particularly } \\
\text { independence, responsibility, } \\
\text { freedom, \& personal relevance }\end{array}$ \\
\hline $\begin{array}{l}\text { King et al. } \\
(2016)\end{array}$ & 81 & Biology & UK & $\begin{array}{l}\text { Students' perceptions } \\
\text { towards inquiry-based } \\
\text { instruction }\end{array}$ & $\begin{array}{l}\text { Survey } \\
\text { questionnaire }\end{array}$ & $\begin{array}{l}\text { Students clearly wanted detailed } \\
\text { instructions, which was not provided } \\
\text { in inquiry-based instruction. } 40 \% \text { of } \\
\text { them said they would value the } \\
\text { opportunity to design \& carry out } \\
\text { their own experiments. } \\
\text { Students believed that explaining } \\
\text { your results to others is an important } \\
\text { part of practical work }\end{array}$ \\
\hline $\begin{array}{l}\text { Leung et al. } \\
(2016)\end{array}$ & 445 & Physics & Canada & $\begin{array}{l}\text { What kinds of } \\
\text { laboratory } \\
\text { technologies do } \\
\text { students prefer? }\end{array}$ & $\begin{array}{l}\text { Internet-based } \\
\text { survey created } \\
\text { through Google } \\
\text { forms }\end{array}$ & $\begin{array}{l}\text { Students preferred physical } \\
\text { equipment in traditional laboratories } \\
\text { more than virtual laboratories }\end{array}$ \\
\hline $\begin{array}{l}\text { Moozeh et } \\
\text { al. (2019) }\end{array}$ & 89 & Chemistry & USA & $\begin{array}{l}\text { Students' preferences } \\
\text { for experiments in a } \\
\text { prelab module } \\
\text { through multimedia } \\
\text { design }\end{array}$ & $\begin{array}{l}\text { Survey } \\
\text { questionnaire \& } \\
\text { videos }\end{array}$ & $\begin{array}{l}\text { Prelab modules helped students } \\
\text { understand theoretical concepts } \\
\text { better than lab manual } \\
\text { Students were attracted to video- } \\
\text { based instruction }\end{array}$ \\
\hline $\begin{array}{l}\text { Sandström e } \\
\text { al. (2014) }\end{array}$ & & Chemistry & Finland & $\begin{array}{l}\text { Perceptions of } \\
\text { learning environment }\end{array}$ & Interview & $\begin{array}{l}\text { Many students expressed a wish to } \\
\text { have more agile learning spaces } \\
\text { outside laboratory. Many of them } \\
\text { reported a need to have differentiated } \\
\text { spaces also either within laboratory } \\
\text { or in close proximity to it }\end{array}$ \\
\hline $\begin{array}{l}\text { Sneddon et } \\
\text { al. (2009) }\end{array}$ & 500 & Physics & UK & $\begin{array}{l}\text { Views of } \\
\text { undergraduate } \\
\text { physics students in } \\
\text { relation to their } \\
\text { experiences of } \\
\text { practical physics at } \\
\text { school }\end{array}$ & $\begin{array}{l}\text { Survey } \\
\text { questionnaire \& } \\
\text { interview }\end{array}$ & $\begin{array}{l}\text { Students preferred clearer guidance } \\
\text { since experiment was confusing }\end{array}$ \\
\hline
\end{tabular}

